\section{INFORMATIKA A STATISTIKA V DOKTORANDSKÉM KURZU LF1 UK}

\section{Štěpán Svačina, Jan HendI}

\section{Souhrn}

Aktuálně je doktorandům Univerzity Karlovy nabízeno několik kurzů z oblasti biomedicínské informatiky. Kličové jsou kurzy dva, z nichž jeden musí student volit povinně: Biomedicínské statistiky pro doktorandy, Kurz Klinická informatika a bioinformatika. Tyto kurzy jsou př́stupné všem doktrandům UK.

\section{Klíčová slova}

biomedicínská informatika, oborová rada, doktorské studium, bioinformatika

\section{Úvod}

Doktorandské studium biomedicínská informatika je jedním z doktorských studijních programů tzv. Biomedicíny. Existuje více než 10 let, aktuálně studuje kolem 50 studentů a ročně proběhne kolem 5 obhajob Ph.D. Klíčové jsou nejen kvalitní publikace studentů ale i vzdělávání. $\mathrm{K}$ tomu slouží tzv. kurzy pořádané oborovou radou Biomedicínská informatika. Kurzy jsou př́stupné všem doktorandům UK. V průběhu celého období byly a i dnes jsou studentům nabízeny kurzy z problematiky simulací či biosignálu, ale hlavní povinný kurz představoval 30 hodinový kurz Klinická informatika a statistika. Při aktuální reakreditaci oboru bylo oponentem vytknuto, že v kurzu je málo obsažena tzv. bioinformatika (problematika informatiky $v$ molekulární biologii) a málo je přednášena problematika analýzy obrazu. Z těchto důvodů a s ohledem na nároky statistiky byl kurz rozdělen na 2 kurzy, tedy 2 x 30 hodin: kurz Biomedicínská statistika pro doktorandy a kurz Klinická informatika a bioinformatika. Poprvé byly kurzy realizovány v červnu 2021. Současně byly zařazeny kurzy analýzy z nabídky akademie věd (doc. Zitová). Jmenované dva kurzy měly strukturu, kterou dále uvádíme.

\section{Kurz Biomedicínské statistiky pro doktorandy}

\section{Pondělí}

1. Svačina Š.: Informatika a statistika.

2. Hendl J.: Opakování principů statistického odhadu a testování, principy Data science analýza

3. Hendl J.: Regresní analýza s jednou proměnnou, transformace

4. Hendl J.: Přehled a klasifikace mnohorozměrných metod, Regresní mnohonásobná analýza (diagnos tika, kvalitativní nezávislé proměnné, víceúrovňová analýza)

\section{Úterý}

5. Hendl J.: Faktorová analýza (explorační, konfirmační)

6. Hendl J.: Diskriminační analýza, logistická analýza

7. Berka P.: Data mining v medicíně 1

8. Berka P.: Data mining v medicíně 2

\section{Středa}

9. Valenta Z.: Analýza přežití

10. Valenta Z.: Neparametrické metody

11. Valenta Z.: Randomizované klinické studie

\section{Čtvrtek}

12. Dušek L., Májek O.: Současné trendy v designu a hodnocení klinických studií
13. Dušek L.: Biomedicínská informatika a biostatistika v řízení a optimalizaci úhrad zdravotní pojištovny

Na začátku kurzu se kladly doktorandům otázky ze základů statistiky. Príslušné znalosti byly jistě zprostředkovány v pregraduálním studiu. Od té doby však neměli obvykle doktorandi mnoho príležitostí si statistickou látku řádně osvojit. To se projevilo v diskusi. Napríklad považovali hodnotu korelace -1 za projev neexistence vztahu.

\section{Kurz Klinická informatika a bioinformatika \\ Pondělí \\ 1. Svačina Š.: Úvod do biomedicínské informatiky \\ 2. Kasal P.: Hodnocení kvality zdravotnické informace \\ 3. Lhotská L.: Systémy pro podporu rozhodování \\ 4. Šoupal J.: Technologie $v$ diabetologii}

\section{Úterý}

5. Kmoch S. a kol. Bioinformatika 1

\section{Středa}

6. Kmoch S. a kol. Bioinformatika 2

\section{Čtvrtek}

7. Dušek L., Blaha M.: Národní zdravotnický informační systém jako základna eHealth v moderním zdravotnictví

8. Blaha M., Dušek L.: Koncepce a hlavní komponenty moderního elektronického zdravotnictví

9. Zvára K.: Informační systémy ve zdravotnictví

10. Zitová B.: analýza obrazu v medicíně

11. Bruthans J.: E-recept u nás a ve světě

$V$ bioinformatice jsou přednášena témata: analýza genomu, molekulárně biologické databáze, principy alignmentu, predikce genů, evoluční stromy, analýza vlastnosti proteinů, geometrická analýza 3D struktur, protein folding, molekulární docking, statisticky aparát bioinformatiky

\section{Závěr}

Na 1. lékařské fakultě je aktuálně vyučována biomedicínská informatika jako povinný předmět pro řadu nelékařských oborů a volitelný pro mediky. Zájemce o informatiku může dále absolvovat výše uvedené doktorské studium oboru Biomedicínská informatika a později může být habilitován či jmenován profesorem v oboru Lékařská informatika. Může tak dosáhnout i velmi vysoké kvalifikace v informatice. Biomedicínská informatika má na 1. lékařské fakultě tradici již od 50 . let minulého století a udržuje si postavení stejně významné jako další lékařské obory

\section{Kontakt}

prof. MUDr. Štěpán Svačina DrSc.

1. lékařská fakulta UK

e-mail:svacinas@lf1.cuni.cz 